\title{
Chemotherapy-induced pulmonary toxicity in lung cancer management
}

\author{
Jorge Roig Cutillas, Elvira Gea Rodríguez and Nuria Barral Viñals ${ }^{a}$ \\ Unitat de Pneumologia. ${ }^{a}$ Servei de Farmàcia. Hospital Nostra Senyora de Meritxell. \\ Escaldes-Engordany (Principality of Andorra).
}

Chemotherapy is the cornerstone of therapy in many stages of lung cancer. Many diagnostic options have to be taken into account when a patient suffering from lung cancer presents with nonspecific, respiratory, clinical manifestations. A multidisciplinary diagnostic approach is then warranted. The top priority is to rule out those life-threatening causes, such as lung infection, that could be properly treated if a right diagnosis is early. To reach a definite diagnosis frequently requires that one or more diagnostic, pneumologic techniques are performed. Regarding to drug-induced pulmonary disease, prevention is mandatory. In this review we have tried to highlight the risk and characteristics of cytostatic-induced pulmonary toxicity caused by those agents that have been commonly employed to treat lung cancer for the last decades. When treating lung cancer patients, a high clinical suspicion of chemotherapy-induced lung toxicity should be kept in mind since an early withdrawal of the offending drug is the most efficacious therapy.

Key words: Lung cancer, chemotherapy, lung toxicity.

Rev Oncología 2001; 4: 183-195.

\section{INTRODUCTION}

Oncologists have often to face a broad differential diagnosis when lung cancer patients under cytos-

Correspondence: Dr. J. Roig.

Unitat de Pneumologia.

Hospital Nostra Senyora de Meritxell.

Av. Fiter i Rosell, 1-13.

Escaldes-Engordany (Principality of Andorra).

Correo electrónico: averoigamypic.ad

Recibido el 10-1-2001.

Aceptado para su publicación el 28-2-2001.
Toxicidad pulmonar inducida por citostáticos en el tratamiento del cáncer de pulmón

La quimioterapia es la opción terapéutica más eficaz en diversos estadios del cáncer de pulmón. El clínico se enfrenta ante un amplio abanico de posibilidades diagnósticas cuando un paciente afecto de cáncer de pulmón presenta manifestaciones clínicas respiratorias inespecíficas. En tal circunstancia es obligada una aproximación diagnóstica multidisciplinaria. La prioridad fundamental es la exclusión de aquellas etiologías susceptibles de un tratamiento eficaz y que representen una amenaza vital para el paciente como es el caso de la infección pulmonar. La confirmación de un diagnóstico etiológico definido va a requeir frecuentemente la adopción de uno o varios procedimientos diagnósticos mediante la práctica de determinadas técnicas neumológicas específicas que deben ser individualizadas en cada caso. En relación a la toxicidad pulmonar inducida por medicamentos, es prioritaria una actitud preventiva. En esta revisión se subrayan los aspectos fundamentales de la toxicidad pulmonar causada por aquellos citostáticos que se han venido utilizando durante las últimas décadas en el tratamiento del cáncer de pulmón. Dado que la retirada precoz del agente causante es la medida terapéutica más eficaz, el oncólogo debe mantener siempre un alto indice de sospecha para la detección de una posible toxi-

tatic treatment present with nonspecific respiratory symptoms and radiographic shadowing ${ }^{1-3}$. Because of their own prognostic and therapeuthic implications the following etiologies have to be firstly considered in the initial diagnostic approach: lung infection, either by conventional pathogens or atypical microorganisms, malignancy-related thromboembolic pulmonary disease, local tumor progression, iatrogenic intra-alveolar hemorrhage, radiotherapy-induced adverse effects, transfusion reactions, postoperative complications 
in those patients that have undergone thoracic surgery, oxygen toxicity, and eventually druginduced pulmonary toxicity. In that last case, most patients are also receiving many drugs, other than cytostatics, that sometimes may cause lung toxicity ${ }^{4}$.

For most clinicians the diagnosis and treatment of pneumonia in an non-immunocompetent patient is often the top priority from a practical point of view. However, it is worthwhile to be aware of other entities that may overlap the clinical presentation of pulmonary infection, as it has been recently emphasized ${ }^{5}$ (table 1

Usually, a multidisciplinary approach is warranted to try to elucidate the cause of new clinical pulmonary findings in lung cancer patients that are treated with chemotherapy, especially when a multimodality therapeutic program is going on. An algorithmic approach to evaluation of pulmonary infiltrates and nonspecific respiratory symptoms and signs in lung cancer patients on chemotherapy is schematically shown in figure 1 . The increasing use of combined chemotherapy and concurrent or alternanting radiotherapy makes it even more dif-

\section{TABLE 1. Noninfectious pulmonary diseases}

\section{mimicking pneumonia}

Acute an chronic eosinophilic pneumonia

Acute inhalation pulmonary injury

Acute chest syndrome associated with adult sickle cell disease

Allergic bronchopulmonary aspergillosis

Alveolar proteinosis

Blood transfusions reactions

Bronchiolitis obliterans organizing pneumonia (BOOP)

Bronchioloalveolar-cell carcinoma

Diffuse alveolar hemorrhage syndromes

Drug-induced or toxic pneumonitis

Exogenous lipid pneumonia

Inflammatory abdominal diseases

Inflammatory pseudotumor (plasma-cell granuloma)

Hypersensitivity pneumonia (extrinsic allergic alveolitis)

Kaposi's sarcoma

Lobar atelectasis

Malignant haemopathies: leukemia, lymphomas, fungoides mycosis

Noninfectious causes of adult respiratory distress syndrome (ARDS)

Oxygen toxicity

Postcardiac injury syndromes

Postpartum antiphospholipid antibodies syndrome

Pulmonary torsion

Pulmonary vasculitis (Wegener's granulomatosis Churg-Strauss syndrome, others)

Radiotherapy-induced pneumonitis

Systemic lupus erythematosus

Sarcoidosis

Thromboembolic pulmonary disease: lung infarcts, Dressler syndrome

From Roig J, et al. Arch Bronconeumol 1998 5 . ficult for clinicians a right diagnostic approach in these circumstances. The progressive trend of lung cancer to be diagnosed in people aged $>70$ years has raised the subject of an alledged increase of drug toxicity in that population ${ }^{6}$. Probably, the multiple underlying diseases which are often present in many elderly patients may afford a better explanation for this finding that age per se. Sometimes physicians have to confront with the dilemma of slowly resolving pulmonary infiltrates in lung cancer patients receiving antibiotics for a confirmed diagnosis of pneumonia. Clinicians have to kept in mind that a slower than usual radiologic resolution of pneumonia may be found in the elderly, in those cases of severe pneumonia with extensive pulmonary shadowing, and with some etiologies such as Legionella ${ }^{5,7}$.

The aim of this article is to review the subject of chemotherapy-induced lung toxicity with a more specific emphasis in those cytostatics that have recently been more commonly used in the therapeutic approach of lung cancer (table 2). Since a variety of mechanisms have been postulated in chemotherapy-induced-pulmonary toxicity but the actual pathogenesis remains speculative ${ }^{8}$, we have focused only in clinically relevant data of the subject. The role of biological response modifiers, hormonal agents, and other non-cytostatic agents in causing adverse respiratory effects is then beyond the scope of this review. Related topics as the radiation sensitizer action of different cytostatics, the interactions of radiotherapy with antineoplastic agents in producing lung damage, and the perioperative considerations of thoracic surgery following chemotherapy have been adressed in other in-depth reviews ${ }^{9-11}$.

\section{GENERAL CONSIDERATIONS}

\section{Clinical features}

Although a certain clinical or radiographic presentation may occasionally be suggestive of pulmonary toxicity caused by a determined cytostatic, it can be in general stated that clinical and radiologic findings are usually not distinctive for any particular chemotherapeutic agent ${ }^{1-4,8}$. Since clinical and radiographic manifestations are protean, it must be emphasized that a high index of clinical suspicion is needed to establish a right diagnosis and institute an appropiate therapy. Affected patients may present with dyspnea, cough, malaise, and sometimes fever. The onset of clinical symptoms is often progressive but a subacute or even abrupt clinical presentation is also possible. In those cases of insidious, progressive pulmonary injury, a relationship between dose and duration of chemotherapy and the onset of lung 


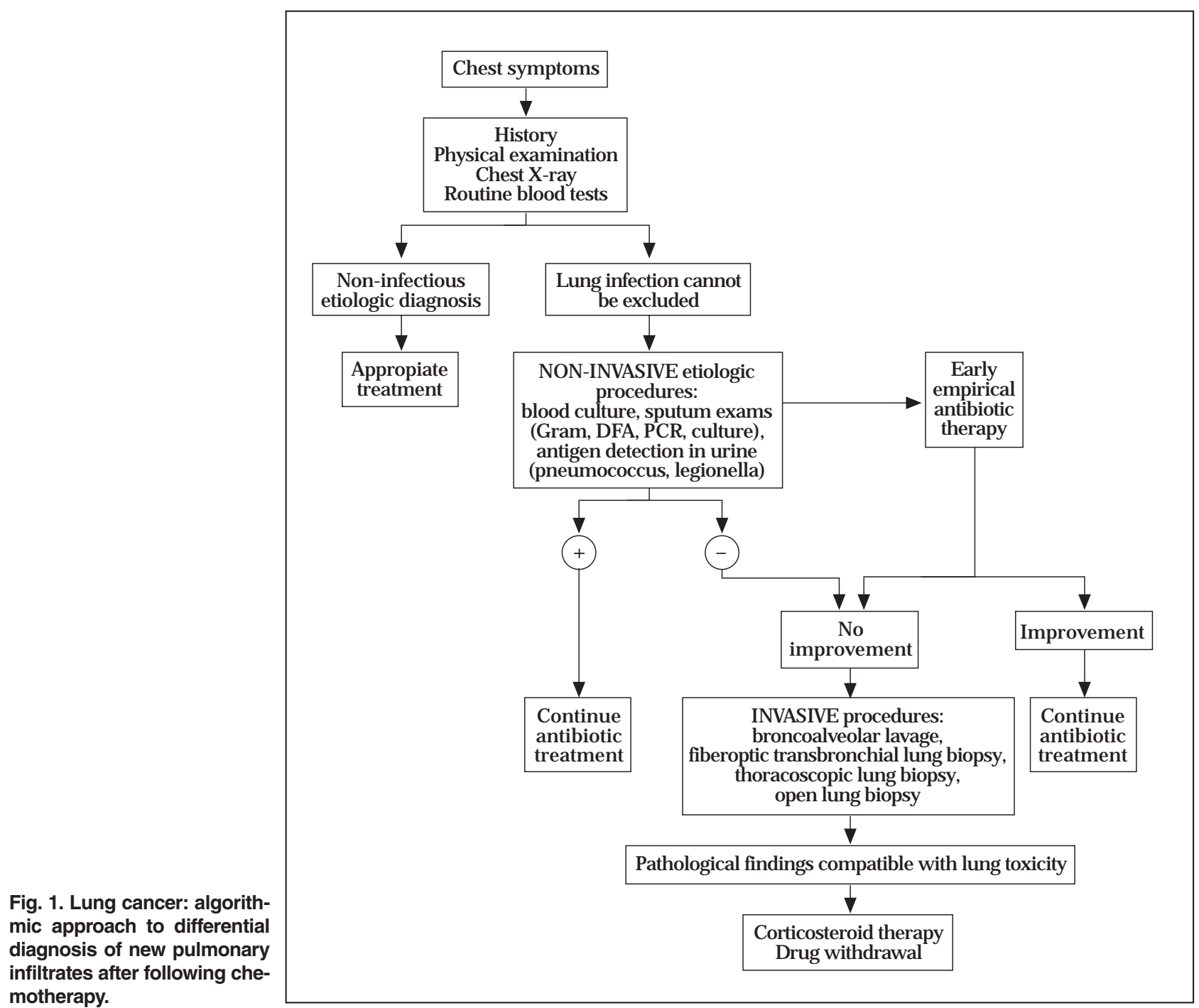

toxicity is not always clear. Those chemotherapeutic agents that have been associated with acute pneumonitis, adult respiratory distress syndrome (ADRS), progressive pulmonary fibrosis, pleural disease, and an hypersensitivity reaction that may cause respiratory symptoms, are shown, respectively, in tables 3, 4, 5, 6 and 7 . The terminology used in many chemotherapy-induced lung toxicity case reports may be sometimes confusing. Some authors prefer to emphasize the pathogical findings, other the clinical picture in a general way, and others chose very specific patophysiological terms such as non-cardiogenic pulmonary edema, acute respiratory failure or acute respiratory distress syndrome (ARDS). In order to clarify these concepts for those readers that are not skilled in pulmonary disease it is worthwhile to remember that neither non-cardiogenic pulmonary edema nor acute respiratory failure are equivalent to ARDS since the diagnosis of this
TABLE 2. Lung cancer: chemotherapeutic agents associated with pulmonary toxicity

\section{Alkylating agents \\ Cyclophosphamide \\ Nitrosureas \\ Ifosfamide \\ Procarbazine \\ Antimetabolites \\ Methotrexate \\ Gemcitabine \\ Cytotoxic antibiotics \\ Mitomycin \\ Doxorubicin* \\ Antimicrotubule agents \\ Vinca alkaloids \\ Paclitaxel \\ Docetaxel \\ Miscellaneous \\ Topotecan \\ Irinotecan \\ Etoposide \\ Teniposide}

* Lung edema secondary to congestive heart failure. 
TABLE 3. Lung cancer: chemotherapeutic agents associated with acute pneumonitis

\author{
Cyclophosphamide \\ Docetaxel \\ Etoposide \\ Gemcitabine \\ Ifosfamide \\ Ipomeanol \\ Irinotecan \\ Methotrexate \\ Mitomycin \\ Paclitaxel \\ Procarbazine \\ Vinca alkaloids
}

last entity requires other additional criteria to be established. The microscopic diagnosis of diffuse alveolar damage usually corresponds to the early histopathological expression of any ARDS, whatever its cause is.

\section{Imaging techniques}

Many different types of radiographic abnormalities have been reported ${ }^{12}$. In general, the chest radiograph findings lag behind the onset of clinical symptoms. Chest CT scan may help to define the extent and characteristics of the opacities ${ }^{13}$. High-resolution CT scan may occasionally detect subtle parenchymal abnormalities when the chest radiograph is still nor$\mathrm{mal}$. On the basis of the differences found in magnetic resonance characteristics, a possible role for magnetic resonance spectrometry could be suggested but further studies are clearly warranted to support this concept ${ }^{14}$. The clinical utility of muclear scintigraphy to both improve sensitivity and to try to correlate the extent 0 disease with the inflamamatory activity is well established ${ }^{15}$. However, gallium scans, as any imaging technique, have inherent limitations in specificity. We think that, when considering a diagnosis of pulmonary drug toxicity, the most important role of any radiologic tecnique is to detect a new abnormality, whatever it is, either in clinically symptomatic patients or as a radiologic finding in a subclinical phase.

\section{Pulmonary function tests}

An early diagnosis of lung toxicity, even before radiographic shadowing appears, may also be suggested

\section{TABLE 4. Lung cancer: chemotherapeutic agents} associated with ADRS

Gemcitabine

Methotrexate

Mitomycin

Paclitaxel

Vinca alkaloids + mitomycin
TABLE 5. Lung cancer: chemotherapeutic agents associated with progressive pulmonary fibrosis

Cyclophosphamide

Etoposide

Methotrexate

Mitomycin

Nitrosureas

if pulmonary function testing shows an unexplained decrease in carbon monoxide diffusing capacity (DLCO) in patients that complain about dyspnea of unknown cause ${ }^{16}$. In contrast to the decreased DLCO usually found in the more common pattern of interstitial lung involvement, an increased DLCO may be sometimes noticed in those rare cases of diffuse alveolar hemorrhage ${ }^{17}$. In severe cases, hypoxemia and an increased alveolar-arterial (A-a) gradient are usually observed. Pulmonary function testing also may help to evaluate the degree of restrictive ventilatory alteration that is often found and to monitorize the functional outcome in a non-invasive way.

Other techniques

Fiberoptic bronchoscopy with bronchoalveolar lavage may be helpful in ruling out an infectious etiology and in supporting the diagnosis of chemotherapy-induced pneumonitis ${ }^{18}$. A nonspecific Iymphocytic predominance with imbalance of the $\mathrm{CD} 4 / \mathrm{CD} 8$ ratio is often observed in certain drug-induced pneumonitis but it should be kept in mind that the clinical usefulness of this finding in diagnosing drug toxicity is clearly limited. In certain cytostatic-induced pulmonar toxicities, such as cyclophosphamide or busulfan, characteristic bizarre pneumocytes in sputum or lavage fluid can be identified. The clinical relevance of a few preliminary studies that suggested the uselfulness of determining serum markers for cytostatic-induced lung toxicity has not been confirmed so far $^{19,20}$.

Pathology

Some attempts have been made to try to correla-

TABLE 6. Lung cancer: chemotherapeutic agents associated with pleural disease

Cyclophosphamide

Docetaxel ${ }^{\star}$

Doxorubicin**

Methotrexate

Mitomycin

Procarbazine

Vinblastine + mitomycin

*Trasudative pleural effussion caused by fluid retention syndrome;

${ }^{* *}$ Trasudative pleural effussion caused by congestive heart failure. 
TABLE 7. Lung cancer: chemotherapeutic agents associated with an hypersensitivity reaction that may cause respiratory symptoms

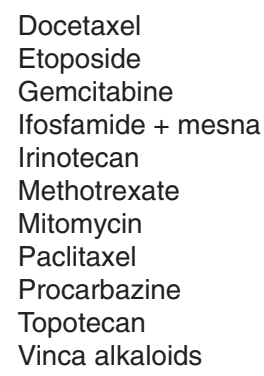

te radiographic findings with the underlying histopathologic process ${ }^{12}$. In those cases of chemotherapy-induced lung toxicity in which a biopsy procedure has been performed, many pathologic patterns, most of them showing a variable degree of an inflammatory component, have been reported $^{21}$. A variety of interstitial pneumonias, usually chronic or nonspecific interstitial neumonia, and many other histologic patterns have been observed (table 8). In cases with a protracted course, different degrees of non-reversible interstitial or alveolar duct fibrosis are found after acute abnormalities have evolved to a late proliferative phase.

\section{Diagnosis}

In summary, the diagnosis of lung toxicity caused by cytostatics in lung cancer patients should be based on clinical history, especially from a chronologic point of

view, nonspecific clinic findings, and the reasonable exclusion of infection and other less common causes of infiltrative lung disease, either patchy or diffusse. As stated before, a multidisciplinary diagnostic approach is mandatory, and the possible need of invasive techniques, such as bronchoalveolar lavage, transbronchial, thoracoscopic or open pulmonary

TABLE 8. Lung cancer: tissue reactions in chemotherapyinduced pulmonary toxicity

Chronic interstitial pneumonia

Diffuse alveolar damage

Bronchiolitis obliterans organizing pneumonia (BOOP)

Obliterative bronchiolitis

Hypersensitivity pneumonia*

Lung fibrosis

Pulmonary edema

Pulmonary hemorrhage

Pulmonary hypertension

Pulmonary veno-occlusive disease

* Presence of poorly formed granulomas in methotrexate-induced lung toxicity. biopsy, has to be considered in some cases in an individualized way.

\section{TREATMENT}

More benign, early detected cases may resolve after cessation of the incriminated cytostatic agent $^{1-4}$. Therefore, the most appropiate treatment for many cases of cytostatic-induced lung toxicity is withdrawal of the offending drug. In the usually more severe case a short course of corticosteroid therapy is warranted. However, the outcome is variable depending on the offending agent and the degree of established lung damage. After an improvement of symptoms is observed, tapering of the dosage has to be instituted on an individualized basis. Lung transplantation has exceptionally been considered in very selected cases for patients cured of a malignancy who had developped chemotherapy-induced fibrosis ${ }^{22,23}$.

\section{ALKYLATING AGENTS}

Table 9 shows a summary of pulmonarv toxicity caused by alkylating agents.

Cyclophosphamide

Two patterns of cyclophosphamide-induced pulmonary toxicity have been clearly identified ${ }^{24}$. Early-onset acute pneumonitis is reversible and responds to discontinuation of the drug or, in more severe cases, to corticosteroid therapy. Clinical features of late-onset pneumonitis are those of progressive pulmonary fibrosis with associated pleural thickening on chest radiograph. These patients do not respond neither to cessation of cyclophosphamide nor to institution of corticosteroid therapy. The incidence of pulmonary injury associated with this cytotoxic agent is not exactly determined but it is thought to be lower than $1 \%$

A syndrome of water retention with marked hypervolemia and hyponatremia may be induced by $\begin{array}{lllll}h & i & g & h & -\end{array}$ dose intravenous cyclophosphamide therapy ${ }^{25}$. Secondary pleuropulmonary findings may then rarely be observed, especially in older patients that receive a fluid overload to prevent hemorrhagic cystitis. In an experimental study cyclophosphamide-induced lung toxicity was shown to be potentiated by hyperoxia ${ }^{26}$. Radiation therapy and cyclophosphamide seem to be a particularly toxic combination for the lung.

\section{Nitrosureas}


TABLE 9. Lung cancer: alkylating agent-induced lung toxicity

\begin{tabular}{|c|c|c|c|c|}
\hline Agent & Clinical presentation & Respiratory features & Incidence & Outcome \\
\hline Cyclophosphamide & $\begin{array}{l}\text { Acute } \\
\text { Chronic }\end{array}$ & $\begin{array}{l}\mathrm{AP} \\
\mathrm{CPF}\end{array}$ & $<1 \%$ & $\begin{array}{l}\text { AP: usually recovery } \\
\text { CPF: high mortality } \\
\text { rate even after } \\
\text { corticosteroid } \\
\text { treatment }\end{array}$ \\
\hline Nitrosurea & $\begin{array}{l}\text { Rarely acute } \\
\text { Usually chronic, } \\
\text { dose-related (total } \\
\text { dose }>1,000 \mathrm{mg} / \mathrm{m}^{2} \text { ) }\end{array}$ & $\begin{array}{l}\mathrm{AP} \\
\mathrm{CPF}\end{array}$ & $\begin{array}{l}<20 \%-30 \% \text { with dose } \\
>1,000 \mathrm{mg} / \mathrm{m}^{2} \\
\text { Increased risk with } \\
\text { concomitant COPD }\end{array}$ & $\begin{array}{l}\text { Mortality may be high } \\
\text { if diagnosis is } \\
\text { delayed }\end{array}$ \\
\hline Procarbazine & Acute & $\begin{array}{l}\text { HR } \\
\text { Rarely AP or pleuritis } \\
\text { Very rarely involvement } \\
\text { of respiratory muscles } \\
\text { in cases of peripheral } \\
\text { neuropathy }\end{array}$ & Very rare & Usually recovery \\
\hline Ifosfamide & Acute & $\begin{array}{l}\text { HR (mesna related) } \\
\text { Acute encephalopathy } \\
\text { respiratory depresion* } \\
\text { Rarely AP }\end{array}$ & CNS depression in $<12 \%$ & Usually recovery \\
\hline
\end{tabular}

* Special concern in advanced COPD and SAS; AP: acute pneumonitis; CPF: chronic pulmonary fibrosis; HR: hypersensitiviy reaction; COPD: chronic obstructive pulmonary disease; SAS: sleep apnea syndrome; CNS: central nervous system.

Bischloroethylnitrosurea (BCNU) and cyclohexylcloroethylnitrosourea (CCNU) have been infrequently used in a few combination chemotherapy regimens for small-cell lung cancer. Pulmonary toxicity, resulting in alveolitis and fibrosis, has been reported after BCNU and CCNU therapy, usually in cumulative doses greater than $1,000 \mathrm{mg} / \mathrm{m}^{2} 2$. Interestingly, preexisting lung disease and abnormal pulmonary function tests, two relatively common findings in lung cancer, have been identified as risk factors for the development of BCNU-induced lung toxicity in a malignant glioma series ${ }^{28}$. In that subset of population a $20 \%-30 \%$ incidence of lung toxicity has been reported ${ }^{27-29}$. Although toxicity is usually dose-related, an acute form of pneumonitis cag occur at either end of the dose schedule ${ }^{30}$.

However, most cases present with the clinical features of an insidious chronic pulmonary fibrosis. Enhanced oxygen toxicity has been reported after $\mathrm{BCNU}$ therapy $^{31}$.

\section{Ifosfamide}

Hypersensitivity reactions, that may imply respiratory manifestations, are possible when ifosfamide is administered, as usual, in conjunction with mesna. The risk of CNS depression following ifosfamide therapy (about $12 \%)^{32}$ has to be taken in consideration in those patients that suffer from advanced chronic obstructive lung disease, a common association in lung cancer, since somnolence may worsen hypercapnia and enhance encephalopathy. A word of caution is also needed in the case of underlying central or obstructive sleep apnea syndrome, since the prevalence of the last one in general population is relatively high. Direct pulmonary toxicity is very rare but possible $e^{33}$.

\section{Procarbazine}

This nonclassic alkylating agent, sometimes used in small-cell lung carcinoma, may cause rarely an hypersensitivity reaction including lung infiltrates that may force discontinuation of the drug $^{34-36}$. Pleural effusion has been occasionally reported ${ }^{37}$. Since procarbazine is used primarily in combination therapy, most reported cases of hypersensitivity have occurred in patients receiving other cytotoxic drugs. Procarbazine is one of the drugs that occasionally may cause neuropathies that could impair respiratory muscle function ${ }^{38}$.

\section{PLATIN COMPOUNDS}

Platin-based regimens have been the goldstandard of combined chemotherapy for the last decade. The lack of any direct pulmonary toxicity is a characteristic of both cisplatin and carboplatin therapies. Two cases of noncardiogenic pulmonary edema associated with hemolytic uremic syndrome had been allegedlly atributted to cisplatin in a 1991 report $^{39}$. In arr opinion, the absence of new references so far and the fact that 
TABLE 10. Lung cancer: antimetabolite agent-induced lung toxicity

\begin{tabular}{|c|c|c|c|c|}
\hline Agent & Clinical presentation & Respiratory features & Incidence & Outcome \\
\hline Methotrexate & $\begin{array}{l}\text { Usually subacute, but } \\
\text { hypersensitivity } \\
\text { acute and pneumonitis } \\
\text { chronic also possible }\end{array}$ & $\begin{array}{l}\text { Usually acute } \\
\text { ARF and chronic fibrosis also possible } \\
\text { Rarely acute encephalopathy* with } \\
\text { respiratory depression (associated } \\
\text { with high-dose therapy) } \\
\text { BHR }\end{array}$ & $2 \%-8 \%$ & $\begin{array}{l}\text { Complete recovery after } \\
\text { corticosteroid therapy } \\
\text { in early diagnosed } \\
\text { cases }\end{array}$ \\
\hline Gemcitabine & Acute & $\begin{array}{l}\text { HR } \\
\text { AP } \\
\text { Rarely ARDS, PVOD }\end{array}$ & $<1 \%$ & $\begin{array}{l}\text { Usually complete } \\
\text { recovery except in } \\
\text { ARDS }\end{array}$ \\
\hline
\end{tabular}

* Special concern in advanced COPD and SAS; ARF: acute respiratory failure; BHR: bronchial hyperreactivity; HR: hypersensitivity reaction; AP: acute pneumonitis; ARDS: adult respiratory distress syndrome; PVOD: pulmonary veno-occlusive disease.

both patients suffered from acute cisplatin nephropaty and that the noncardiogenic edema seemed to be triggered by a red blood cell transfusion make this association very doubtful. Adverse lung effects have not been reported so far with the new orally available platinum-containing anticancer drugs.

\section{ANTIMETABOLITES}

Table 10 shows a summary of pulmonary toxicity caused by antimetabolites.

\section{Methotretxate}

The role of this folate antagonist as a therapeutic agent seems to be nowadays more in the field of autoimmune disease than in that of lung cancer ${ }^{40}$. Al-though a subacute clinical presentation is most common, acute and chronic forms also occur. Pulmonary toxicity may be diagnosed as early as a few days and as late as many years of treatment ${ }^{41}$. The incidence of pulmonary toxicity has been a matter of controversy but present studies estimate a rate of $2 \%$ to $8 \%$. Difficulties found in comparing the incidence and characteristics of methotrexate-induced lung toxicity among series promoted the scoring system published by Searles et al in $1987^{42}$. In a large study on methotrexate induced lung injury following treatment for rheumatoid arthritis a few risk factors were identified: age greater than 60 years, hypoalbuminemia, diabetes mellitus, and rheumatoid pleuropulmonary involvement ${ }^{43}$.

The most frequent pulmonary manifestation is hypersensitivity pneumonitis, with peripheral blood eosinophilia that may be observed in up to $40 \%-$ $50 \%$ of patients. Lymphocitic predominance with an increase in $\mathrm{CD} 4+\mathrm{T}$ cells and $\mathrm{CD} 4 / \mathrm{CD} 8$ ratio in bronchoalveolar lavage fluid, and a characteristic pathologic pattern of poorly defined gramulomatous infil- tration with interstitial mononuclear infiltrates have also been consistently reported ${ }^{44}$. A fulminant presentation of respiratory failure has been well described, even after intrathecal administration in nonpulmonary malignancies. The unusual radiographic finding of hilar adenopathy has been very occasionally reported. Acute chest pain caused by pleuritis without parenchymal involvement may rarely occur $^{45}$. While the drug has been used to control severe corticosteroid-dependent bronchial asthma, methotrexate-induced bronchial hyperreactivity has been paradoxically reported. A reversible pulmonary non-Hodgkin's B-cell Iymphoma may appear in patients under methotrexate therapy. Characteristically, it may regress after cessation of the drug. An interesting association with Epstein-Barr virus infection has been reported ${ }^{46}$.

Acute encephalopathy that may present with confusion and even coma has been reported with high-dose therapy. Respiratory implications in severe COPD, in a manner similar to ifosfamide, must be remembered by clinicians.

Piritrexim, a methrotrexate analog that has been ocasionally used in upper respiratory tract tumors, which are commonly associated with lung cancer, may also cause pulmonary toxicity ${ }^{47}$.

\section{Fluoruracil}

The use of fluorinated pyrimidines in lung cancer has been mostly restricted to Japanese studies. To the best of our knowledge, significant pulmonary toxicity has not been reported so far. Fluoruracil administration could enhance the risk of mitomycin-induced thrombotic microangiopathy with acute respiratory distress syndrome ${ }^{8}$.

\section{Gemcitabine}

This pyrimidine analog shows a good activity against 
TABLE 11. Lung cancer: antibiotic agent-induced lung toxicity

\begin{tabular}{|c|c|c|c|c|}
\hline Agent & Clinical presentation & Respiratory features & Incidence & Outcome \\
\hline Mitomycine & $\begin{array}{l}\text { Acute } \\
\text { Chronic, dose-related } \\
\quad\left(\text { total dose }>30 \mathrm{mg} / \mathrm{m}^{2}\right)\end{array}$ & $\begin{array}{l}\text { AP } \\
\text { Rarely ARF } \\
\text { Very rarely thrombotic } \\
\text { microangiopathy with } \\
\text { ARDS }\end{array}$ & $3 \%-12 \%$ & $\begin{array}{l}\text { Fatality rate of } 40 \% \text { even after } \\
\text { corticosteroid treatment } \\
\text { Increased risk of ARDS if oombined } \\
\text { therapy with vinca alkaloids } \\
\text { Increased risk of microangiopathy if } \\
\text { associated with fluoruracil } \\
\text { (highest mortality) }\end{array}$ \\
\hline Doxorubicine & $\begin{array}{l}\text { Late, dose-related } \\
\text { (total dose }>500 \mathrm{mg} / \mathrm{m}^{2} \text { ) }\end{array}$ & $\mathrm{CHF}$ & $<10 \%$ & $\begin{array}{l}\text { Poor outcome if severe CHF is } \\
\text { already present at diagnosis }\end{array}$ \\
\hline
\end{tabular}

ARF: acute respiratory failure; BHR: bronchial hyperreactivity; HR: hypersensitivity reaction; AP: acute pneumonitis; ARDS: adult respiratory distress syndrome; CHF: congestive heart failure.

a wide range of solid tumors, including lung cancer. Consequently, it has become one of the most widely used cytostatics in the therapeutic approach of lung tumors. One benign respiratory side effect of gemcitabine is dyspnea, which may start within a few hours of administration of the drug and is thought to be related to bronchospasm $^{48-52}$. A potentially more serious event is the appearance of parenchymal infiltrates that sometimes may be associated with acute respiratory distress syndrome ${ }^{53-56}$. A few fatalities atributted to diffuse alveolar damage and ARDS have been reported. Since that drug shows an structure and metabolism quite similar to cytosine arabinoside (ara-C) a capillary leak phenomena has also been allegedlly incriminated in gemcitabine-induced pulmonary toxicity. Rare instances of pulmonary veno-occlusive disease and hemolytic uremic syndrome have been reported ${ }^{57,58}$. A recent German study reported a worrying 7.1\% percentage of unexplained non-cardiogenic pulmonary distress «most likely related to gemcitabine» in a series of 56 patients ${ }^{56}$. A more extensive retrospective study based on 4,448 trial patients shows a $0.45 \%$ incidence of serious pulmonary toxicity $^{50}$. Although high dose steroid pretreatment has allowed succesful rechallenge with gemcitabine after initial severe pulmonary toxicity in a few instances, this approach does not seem to be prudent since a potential risk of repeated toxicity with reexposure can not be definitely avoided. Although many pulmonary toxicities caused by gemcitabine are mild, oncologists must be aware of possible life-threatening cases in order to administer corticosteroid therapy in a timely fashion $^{59}$.

Concern about an increased risk of severe pulmonary toxicity in patients treated with a combination of gemcitabine and docetaxel has been reported $^{60,61}$.

\section{ANTIBIOTICS}

Table 11 shows a summary of pulmonary toxicity caused by antibiotics.

\section{Mitomycin}

Although mitomycin-induced pulmonary toxicity is unpredictable the reported global range of significant pulmonary reactions from mitomycin is $3 \%-12 \%$ and more likely to occur at higher dosages $^{62-68}$. Mitomycin lung toxicity can not be prevented with corticosteroid pre-medication. An acute or subacute pneumonitis, sometimes with bronchospasm and acute respiratory failure, and also a more chronic, progressive form, have both been described. Chronic pneumonitis seems to be related to the total dose of the drug administered and it is very uncommon when the cumulative dose is less than $30 \mathrm{mg} / \mathrm{m}^{2}$. Most cases of mitomycin-induced lung damage occur when a vinca alkaloid is administered concomitantly ${ }^{8}$. In that population lifethreatening reactions, such as severe noncardiogenic edema and adult respiratory distress syndrome with diffuse alveolar damage, have been reported ${ }^{63,64,66}$. When mitomycin is administered as part of a combination neoadjuvant chemotherapy, lung toxicity may be enhanced by high concentrations of oxygen during surgery $^{69,70}$. It has been suggested that the administered oxygen concentration should not exceed a $\mathrm{FiO}_{2}$ of 0.5. Pleural involvement is an uncommon radiographic finding. Type I and type II cells atypia is also possible, a cytological finding similar to those that may be observed after busulfan or cyclophosphamide therapy. Once pulmonary toxicity has been diagnosed withdrawal of the drug and the institution of corticosteroid therapy may not avoid a progressive respiratory failure in up to $40 \%$ of cases. Pulmonary toxicity has also been reported with the new mitomycin analogs, such as $\mathrm{KW}-2149^{71}$. 
TABLE 12. Lung cancer: antimicrotubule agent-induced lung toxicity

\begin{tabular}{|c|c|c|c|c|}
\hline Agent & Clinical presentation & Respiratory features & Incidence & Outcome \\
\hline Vinca alcaloids & Acute & $\begin{array}{l}\mathrm{HR} \\
\mathrm{AP}\end{array}$ & $\begin{array}{l}\text { Dyspnea in }<5 \% \text { of patients } \\
\text { receiving vinorelbine }\end{array}$ & $\begin{array}{l}\text { Usually recovery. } \\
\text { Rarely ARDS with high } \\
\text { mortality if associated } \\
\text { with mitomycin }\end{array}$ \\
\hline Paclitaxel & Acute & $\begin{array}{l}\mathrm{HR} \\
\mathrm{AP}\end{array}$ & $\begin{array}{l}\mathrm{HR}<1 \% \text { with pretreatment } \\
\mathrm{AP} \text { rare if dosage }<350 \mathrm{mg} / \mathrm{m}^{2}\end{array}$ & $\begin{array}{l}\text { Usually recovery with } \\
\text { mandatory pretreatment } \\
\text { Risk of ARDS if high dose } \\
\text { therapy or concomitant } \\
\text { radiotherapy }\end{array}$ \\
\hline Docetaxel & Acute or chronic & $\begin{array}{l}\text { AP } \\
\text { Fluid retention syndrome }\end{array}$ & $\begin{array}{l}\text { AP very rare } \\
\text { Increased risk of water } \\
\text { retention if dose }>400 \mathrm{mg} / \mathrm{m}^{2}\end{array}$ & $\begin{array}{l}\text { Usually complete } \\
\text { recovery }\end{array}$ \\
\hline
\end{tabular}

HR: hypersensitivity reaction; AP: acute pneumonitis.

The most severe form of pulmonary reaction from mitomycin is a thrombotic microangiopathy with renal failure, hemolytic anemia, and noncardiogenic pulmonary edema ${ }^{72}$. This entity overlaps the «hemolytic uremic syndrome» and causes an adult respiratory distress syndrome in approximately $50 \%$ of cases.

Blood transfusions and 5-fluoruracil have been allegedly incriminated in the appearance of this distinctive syndrome ${ }^{8}$. The syndrome is unusual, especially if a low cumulative dose is administered, but the progmosis is poor since the overall case-fatality rate is about $70 \%^{\circ}$.

\section{Doxorubicin. Daunorubicin. Epirubicin}

Abnormal pulmonary findings in patients receiving anthracycline antibiotics are usually secondary to primary cardiac toxicity ${ }^{1-4}$, which has been reported in up to $10 \%$ of patients and seems to be related to cumulative dose. The risk of congestive heart failure seems to remain low until a total dose of 450 to $550 \mathrm{mg} / \mathrm{m}^{2}$ has been reached. However, severe congestive myocardiopathy is possible even after a single dose and it has been suggested that the risk of congestive heart failure begins to increase at total doses of doxorubicin above $350 \mathrm{mg} / \mathrm{m}^{2}$ or $700 \mathrm{mg} / \mathrm{m}^{2}$ of daunorubicin $^{73}$. Doxorubicin may rarely produce pleural disease.

\section{VINCA ALKALOIDS}

Table 12 shows a summary of pulmonary toxicity caused by antimicrotubule agents, including vinca alkaloids and taxanes.

When used alone, the vinca alkaloids are very rare causes of direct lung toxicity ${ }^{74,75}$. Most reported cases are associated with combined mitomycin chemotherapy or radiotherapy ${ }^{63,64,66}$. Acute pulmonary edema after intravenous vinblastine infusion has been noted ${ }^{76}$. Dyspnea of unclear etiology has been observed following administration of vindesine used in combination with $\mathrm{mi}-$ tomycin- $\mathrm{C}^{77}$. Vincristine is one of the drugs that can impair respiratory muscle function ${ }^{38}$. Although sensory neuropathies are usually the most common manifestation, motor or sensorimotor neuropathies may also occur. Involvement of respiratory muscles is rare but possible.

\section{Vinorelbine}

Vinorelbine is now probably the most widely used vinca alkaloid in the treatment of lung cancer ${ }^{74}$. Dyspnea has been reported to occur in up 5\% of patients. An acute bronchospasm, similar to an hypersensitivity reaction, or an subacute clinical presentation with dyspnea and cough have both been observed. The last one usually occurs within one hour after treatment and the chest radiograph occasionally may show a patchy interstitial shadowing $^{75}$.

\section{TAXANES}

\section{Paclitaxel}

Paclitaxel has emerged as one of the most efficacious cytostatics in the therapeutic approach of lung cancer. Before premedication with corticosteroids up to $30 \%$ of patients in early trails suffered from dyspnea caused by bronchospasm and other symptoms, such as rash and hypotension, secondary to anaphylaxis ${ }^{78-80}$. The mechanism seems to be a direct injury to basophils that causes an immediate histamine release. The routine administration of antihistaminics, corticosteroids, and H2 blockers, before paclitaxel intravenous inphusion, has decreased the incidence of that hypersensiti$v \quad i \quad t \quad y$ to about 1\%. Interestingly, parenteral desensitization to paclitaxel has been reported with succesful 
results.

A different type of pulmonary damage is that derived from direct pulmonary toxicity, which seems to be dose-related ${ }^{81-86}$. With doses less than $350 \mathrm{mg} / \mathrm{m}^{2}$ lung

toxicity seems to be extremely rare. Transient pulmonary infiltrates have been occasionally reported. More serious pulmonary toxicities have been observed with

high dose paclitaxel therapy, particularly when combined with other cytostatics in the setting of patients that undergo bone marrow transplantation.

The use of concurrent lung irradiation and paclitaxel therapy deserves a few comments ${ }^{87-93}$. Compared to other radiosensitizer cytostatics, a higher than usual enhancement of radiation-induced lung damage has been reported. At least in one study, this combination modality therapy was associated, to some extent, with an increased risk of postoperative complications in stage lll lung cancer patients ${ }^{94}$.

However, differences in drug combinations and radiation doses among studies suggest that larger, prospective studies are warranted before any definite conclusion is reached. A recall pneumonitis may be very uncommonly observed in patients previously treated with radiotherapy.

\section{Docetaxel}

A very unusual acute difusse interstitial pneumopathy has been described ${ }^{95}$. As stated before, a few cases of lung toxicity caused by combined therapy wih docetaxel and gemcitabine have been reported ${ }^{60,61}$. Hypersensitivity mechanisms are thought to be incriminated since recovery is rapid after steroid therapy.

The appearance of a pleural effusion, often moderate, in patients that are being treated with docetaxel, should not be misdiagnosed as a pleuropulmonary side-effect of the drug. A fluid retention syndrome, sometimes causing weight gain as well as pleural effusion and ascitis, is a characteristic and unexplained toxicity of that drug. The incidence and severity of this fluid-retention syndrome increases at cumulative doses of $400 \mathrm{mg} / \mathrm{m}^{2}$ or greater.

\section{CAMPTOTHECINS}

Topotecan. Irinotecan

The topoisomerase I inhibitors, topotecan and irinotecan, have been used in the treatment of refractory or relapsed small-cell lung cancer.

A very low rate of reversible pulmonary toxicity, basically mild to moderate dyspnea, has be- en observed with topotecan. In a phase II study of topotecan in malignant mesothelioma, one out of 22 patients had a grade 2 pulmonary toxicity ${ }^{96}$. Transitory dyspnea in up to $22 \%$ of patients, coughing, and rhinitis are possible respiratory adverse effects when irinotecan (CPT-11) is administered. More serious events such as dyspnea with radiographic infiltrates and fever show an incidence range of $1 \%$ to $3 \%{ }^{97,98}$. However in a large phase II Japanese trial with a dose of $100 \mathrm{mg} / \mathrm{m}^{2}$ weekly up to 8\% of patients had pulmonary toxicity. In another Japanese trial of 16 patients that received the irinotecan as a second-line therapy with the same weekly schedule, 2 patients had extensive pulmonary shadowing $(13 \%)^{100}$. In concurrent chemoradiotherapy for lung cancer, CPT11 has been identified in multivariate analysis as a significant risk factor associated with eventual development of pneumonitis ${ }^{101}$.

\section{EPIPODOPHYLLOTOXINS}

Etoposide. Teniposide

These topoisomerase II inhibitors keep a significant role in the treatment of small-cell lung cancer. Although etoposide (VP-16) shows a distinctive low risk profile of general toxicity a very few cases of biopsy-proven pulmonary toxicity have been reported ${ }^{102-105}$. A fatality after following oral therapy has also been observed ${ }^{103}$. A very rare hypersensitivity reaction including loss of consciousness, non-specific chest pain, and bronchospasm is also possible after etoposide infusion $^{104}$.

Teniposide (VM-26) was reported to have produced an acute lung injury in one case but the significance of that report is unclear since the patient had previously received $\mathrm{BCNU}^{1}$.

\section{POMEANOL}

Ipomeanol (IPO) has been administered to nonsmall cell lung cancer patients in a phase I trial with a reported preliminary rate of serious (grade 4) pulmonary toxicity of about $2 \%^{106}$.

\section{CONCLUSION}

Chemotherapy-induced lung toxicity may have a substantial impact on the prognosis of lung cancer partients that follow cytostatic therapy. Although the incidence is in general low, oncologists must we aware of this entity since if it remains unrecognized the likelihood of a fatal outcome is clearly increased.

Several lines of evidence support the notion that 
an early diagnosis of any drug-induced pulmonary toxicity is mandatory to improve survival. The clinical relevance of such an early diagnosis is supported by the need of an immediate withdrawal of the offending drug and the early institution of corticosteroid therapy in severe cases. The challenging setting of lung cancer patients that present with respiratory symptoms and clinical findings of unkown etiology should be approached from a multidisciplinary point of view.

\section{References}

1. Cooper JAD, White DA, Matthay RA. Drug-induced pulmonary disease. Part 1: cytotoxic drugs. Am Rev Respir Dis 1986; 133: 321-340.

2. Kreisman H, Wolkove N. Pulmonary toxicity of antineoplastic therapy. Semin Oncol 1992; 19: 508-520.

3. De Castro J, Viches Y, González M. Toxicidad pulmonar en el tratamiento del cáncer. Med Clín (Barc) 1995; 105: 661-668.

4. Carrión F, Marín J. Toxicidad pulmonar por fármacos. Arch Bronconeumol 1999; 35: 550-559.

5. Roig J, Martínez J, Domingo C. Concepto y diagnósti co diferencial de la neumonía. Arch Bronconeumol 1998; 34 (Supl 2) : 3-10.

6. Stephens RJ, Johnson DH. Treatment and outcomes for elderly patients with small cell lung cancer. Drugs Aging 2000; 17: 229-247.

7. Roig J, Domingo C, Morera J. Legionnaires' disease. Chest 1994; 105: 1.817-1.825.

8. Twohig KJ, Matthay RA. Pulmonary effects of cytotoxic agents other than bleomycin. Clin Chest Med 1990; 11: 31-54.

9. Yamada M, Kudoh S, Hirata $K$, Nakajima T, Yoshikawa I Risk factors of pneumonitis following chemoradiotherapy for lung cancer. Eur J Cancer 1998; 34: 71 75.

10. Tannock IF. New perspectives in combined radiotherapy and chemotherapy treatment. Lung Cancer 1994; 10 (Supl 1) : 29-51.

11. Ginsberg RJ, Goldberg M. Pulmonary resection following chemotherapy perioperative considerations. In: Peters R, Toledo J, ed. Perioperative care. Amsterdam: Elsevier Science Publishers, 1992; 210-217.

12. Rossi SE, Erasmus JJ, McAdams HP, Sporn TA, Goodman PC. Pulmonary drug toxicity: radiologic and pathologic manifestations. Radiographics 2000; 20: 1.245-1.259.

13. Taylor $\mathrm{CR}$. Imaging techniques in the evaluation of drug-induced pulmonary disease. Clin Chest Med 1990; 11: 8793.

14. Hatabu H, Stock KW, Sher S, et al. Magnetic resonance imaging of the thorax. Past, present, and future. Clin Chest Med 1999; 20: 775-803.

15. Moinuddin M. Radionuclide scanning in the detection of drug-induced lung disorders. J Thorac Imaging $1991 ; 6: 62-67$.

16. Castro M, Veeder MH, Mailliard JA, Tazelaar HD, Jett JR. A prospective study of pulmonary function in patients receiving mitomycin. Chest 1996; 109: 939944 .

17. Greening AP. Serial estimations of carbon monoxide diffusing capacity in intrapulmonary haemorrhage. Clin Sci (Colch) 1981; 60: 507-512.

18. Stover DE, Zaman MB, Hadju Sl, Lange M, Gold J,
Armstrong D. Bronchoalveolar lavage in the diagnosis of diffuse pulmonary infiltrates in the immunosuppressed host. Ann Intern Med 1984; 101: 1-7.

19. Anscher MS, Peters WP, Reisenbichler H, et al. Transforming growth factor beta as a predictor of liver and lung fibrosis after autologous bone marrow transplantation for advanced breast cancer. N Engl J Med 1993; 328: 1.592-1.598.

20. Villani F, Bacchella L, Bulgheroni A, et al. Study of functional and biochemical indicators of subclinical lung damage in bleomycin-treated patients. Respir Med 1992; 86: 327-333.

21. Walker Smith GJ. The histopathology of pulmonary reactions to drugs. Clin Chest Med 1990; 11 (1): 95-117.

22. Grossman RF, Frost A, Zamel N, et al. Results of single-lung transplantation for bilateral pulmonary fibrosis. The Toronto Lung Transplantation Group. N Engl J Med 1990; 322: 727-733.

23. Santamauro JT, Stover DE, Jules-Elysee K, Maurer JR. Lung transplantation for chemotherapy-induced pulmonary fibrosis. Chest 1994; 105: 310-312.

24. Mailik SW, Myers JL, De Remee RA, Specks U. Lung toxicity associated with cyclophosphamide use. Two distinct patterns. Am J Respir Crit Care Med 1996; $154: 1.851-1.865$.

25. Bressler RB, Huston DP. Water intoxication following moderate dose intravenous cyclosphophamide. Arch Intern Med 1985; 145: 548-549.

26. Hakkinen PJ, Whiteley JW, Witschi HR. Hyperoxia, but not thoracic $\mathrm{X}$-irradiation, potentiates bleomycin and cyclophosphamide-induced lung damage in mice. Am Rev Respir Dis 1982; 126: 281-285.

27. Crittenden D, Tranum BL, Hunt A. Pulmonary fibrosis after prolonged therapy with 1,3-bis (2-chloroethyl)1-nitrosourea. Chest 1977; 72: 372-373.

28. Aronin PA, Mahaley MS, Rudnick SA, et al. Prediction of BCNU pulmonary toxicity in patients with malignant gliomas. An assessment of risk factors. N Engl J Med 1980; 303: 183-188.

29. Selker RG, Jacobs SA, Moore PB. BCNU (1,3-bis (2chloroethyl)-1-nitrosourea) - induced pulmonary fibrosis. Neurosurgery 1980; 7: 560-565.

30. Litam JP, Dail DH, Spitzer G, et al. Early pulmonary toxicity after administration of high-dose BCNU. Cancer Treat Rep 1981; 65: 39-44.

31. Kehrer JP, Paraidathathu T. Enhanced oxygen toxicity following treatment with 1,3-bis (2-chloroethyl)1-nitrosourea. Fundam Appl Toxicol 1984; 4: 760767.

32. Cameron JC. Ifosfamide neurotoxicity. A challenge for nurses, a potential nightmare for patients. Cancer Nurs 1993; 16: 40-46.

33. Baker WJ, Fistel SJ, Jones RV. Interstitial pneumonitis associated with ifosfamide therapy. Cancer 1990; 65: 2.217-2.221.

34. Lokich JJ, Moloney WC. Allergic reaction to procarbazine. Clin Pharmacol Ther 1972; 13: 573-574.

35. Ecker MD, Jay B, Keohane MF. Procarbazine lung. Am J Roentgenol 1978; 131: 527-528.

36. Garbes ID, Henderson ES, Gómez GA, et al. Procarbazine-induced interstitial pneumonitis with a normal chest X-ray: a case report. Med Pediatr Oncol 1986; 14: 238-241.

37. Jones SE, Moore M, Blank N, et al. Hypersensitivity of procarbazine (Matulane) manifested by fever and pleuropulmonary reaction. Cancer 1972; 29: 498- 
500 .

38. Aldrich TK, Prezant D. Adverse effects of drugs on the respiratory muscles. Clin Chest Med 1990; 11: 177-189

39. Khansur T, Kennedy A. Case report: cisplatin-induced hemolytic uremic syndrome. Am J Med Sci 1991; 301: 390-392.

40. Lynch JPIII, McCune WJ. Immunosuppressive and CYtotoxic pharmacotherapy for pulmonary disorders. Am J Respir Crit Care Med 1997; 155: 395-420.

41. Sostman HD, Matthay RA, Putnam CE, Smith GJ. Methotrexate induced pneumonitis. Medicine 1976; 55: 371-388.

42. Searles G, MCKendry RJR. Methotrexate pneumonitis in rheumatoid arthritis: potential risk factors. J Rheumatol 1987; 14: 1.164-1.171.

43. Alarcón GS, Kremer JM, Malacuso M, et al. Risk factors for methotrexate-induced lung injury in patients with rheumatoid arthritis: a multicenter, case-control study. Methotrexate-Lung Study Group. Ann Intern Med 1997; 127: 356-364.

44. White DA, Rankin JR, Stover DE, Gellene RA, Gupta S. Methotrexate pneumonitis: lavage findings suggest an immune mediated disorder. Am Rev Respir Dis 1989; 139: 18-21.

45. Urban C, Nirenberg A, Caparros B, Anac S, Cacavio A, Rosen G. Chemical pleuritis as the cause of acute chest pain following high-dose methotrexate treatment. Cancer 1983; 51: 34-37.

46. Kamel OW, Van de Rijn M, Weiss LM, et al. Brief report: reversible Iymphomas associated with EpsteinBarr virus during methotrexate therapy for rheumatoid arthritis and dermatomyositis. N Engl $\mathrm{J}$ Med 1993; 328: 1.317-1.321.

47. De Wit R, Verweij J, Slingerland R, Stoter G. Piritrexim-induced pulmonary toxicity. Am $\mathrm{J} \mathrm{Clin}$ Oncol 1993; 16: 146-148.

48. Brose MS, Cheng JM, Haller DG. Incidence of pulmonary and non-hematologic toxicities related to gemcitabine. Proc ASCO 2000; 761.

49. Roychowdhury DF, Smith CA, Peterson PP, et al. Infrequency of serious pulmonary toxicity (SPT) with Gemzar (G) : analysis of a large database. Proc ASCO 2000; 762 .

50. Sara S, King E, Unger M, Langer C. Retrospective analysis of gemcitabine induced pulmonary toxicity: critical management issues. Proc ASCO 2000; 2.402 .

51. Kelly K. Future directions for new cytotoxic agents in the treatment of advanced-stage non-small-cell lung cancer. Educational Book ASCO 2000; 357-367.

52. Ciotti R, Belotti G, Facchi E, Cantu A, D'Amico A, Gatti C. Sudden cardiopulmonary toxicity following single infusion of gemcitabine. Ann Oncol 1999; 10: 997.

53. Tempero MA, Brand R. Fatal pulmonary toxicity resulting from treatment with gemcitabine. Cancer 1998; 82: 1.800-1.801.

54. Pavlakis N, Bell DR, Millward MJ, Levi JA. Fatal pulmonary toxicity resulting from treatment with gemcitabine. Cancer 1998; 82: 286-291.

55. Marruchella A, Fiorenzano G, Merizzi A, Chiodera PL. Diffuse alveolar damage in a patient treated with gemcitabine. Eur Respir J 1998; 11: 504-506.

56. Sauer-Heilborn A, Kath R, Schneider CP, Hoffken K. Severe non-haematological toxicity after treatment with gemcitabine. J Cancer Res Clin Oncol 1999; 125: 637-640.

57. Nackaerts KL, Daenen M, Vansteenkiste JF, Vandelvelde A, Van Bleyenbergh P, Demedts MG. Hemolytic uremic syndrome caused by gemcitabine. Ann Oncol $1998 ; 9$ : 1.355-1.356.

58. Vansteenkiste J, Bomans P, Verbeken EK, Nackaerts KL, Demedts MG. Fatal pulmonary veno-occlusive disease possibly related to gemcitabine. Lung Cancer 2001; 31 : 83-85.

59. Vander Els NJ, Miller V. Succesful treatment of gemcitabine toxicity with a brief course of oral corticosteroid therapy. Chest 1998; 114: 1.779-1.781.

60. Dunsford ML, Mead GM, Bateman AC, Cook T, Tung K. Severe pulmonary toxicity in patients with a combination of docetaxel and gemcitabin for metastatic transitional cell carcinoma. Ann Oncol 1999; 10: 943-947.

61. Briasoulis E, Froudarakis M, Milionis HJ, Peponis I, Constantopoulos S, Pavlidis N. Chemotherapy-induced noncardiogenic pulmonary edema related to gemcitabine plus docetaxel combination with granulocyte colony-stimulating factor support. Respiration 2000; 67: 680-683.

62. Okuno SH, Frytak S. Mitomycin lung toxicity. Acute and chronic phases. Am J Clin Oncol 1997; 20: 282284 .

63. Raderer M, Kornek G, Hejna M, Vorbeck F, Weinlaender G, Scheithauer W. Acute pulmonary toxicity associated with high-dose vinorelbine and mitomycin $\mathrm{C}$. Ann Oncol 1996; 7: 973-975.

64. Rivera MP, Kris MG, Gralla RJ, White DA. Syndrome of acute dyspnea related to combined mitomycin plus vinca alkaloid chemotherapy. Am J Clin Oncol 1995; 18: 245-250.

65. Linette DC, MCGee KH, MCFarland JA. Mitomycin-induced pulmonary toxicity: case report and review of the literature. Ann Pharmacother 1992; 26: 481484 .

66. Rao SX, Ramaswamy G, Levin M, McCravey JW. Fatal acute respiratory failure after vinblastine-mitanycin therapy in lung carcinoma. Arch Intern Med 1985; 145: 1.905.

67. Verweij J, Van Zanten T, Souren T, Golding R, Pinedo HM. Prospective study on the dose relationship of mitomycin C-induced interstitial pneumonitis. Cancer 1987; 60: 756-761.

68. Orwoll ES, Kiessling BJ, Patterson JR. Interstitial pneumonia from mitomycin. Ann Intern Med 1978; 89: 352355 .

69. Thompson CC, Bailey MK, Conroy JM, Bromley HR. Postoperative pulmonary toxicity associated with mitomycin-C therapy. South Med J 1992; 85: 1.2571.259 .

70. Klein DS, Wilds PR. Pulmonary toxicity of antineoplastic agents: anaesthetic and postoperative implications. Can Anaesth SoC J 1983; 30: 399-405.

71. Schrijvers D, Catimel G, Highley M, et al. KW-2149induced pulmonary toxicity is not prevented by corticosteroids: a phase I and pharmacokinetic study. Anticancer Drugs 1999; 10: 633-639.

72. Sheldon R, Slaughter DA. A syndrome of microangiopathic hemolytic anemia, renal impairment, and pulmonary edema in chemotherapy-treated patients with adenocarcinoma. Cancer 1986; 58: 1.4281.436 .

73. Von Hoff DD, Layard MW, Basa P, et al. Risk factors for doxorubicin-induced congestive heart failure. Ann Inntern Med 1979; 91: 710-717.

74. Hohneker JA. A summary of vinorelbine (Navelbine) safety data from North American clinical trials. Semin Oncol 1994; 21 (Supl 10) : 42-46. 
75. Kourokis C, Hings I. Respiratory failure following vinorelbine tartrate infusion in a patient with non-small cell lung cancer. Chest 1997; 112: 846-848.

76. Israel RH, Olson JP. Pulmonary edema associated with intravenous vinblastine. JAMA 1978; 240: 1.585 .

77. Kris MG, Pablo D, Gralla RJ, Burke MT, Prestifilippo J,
Lewin D. Dyspnea following vinblastine or vindesine administration inn patients receiving mitomycin plus vinca alkaloid combination therapy. Cancer Treat Rep 1984; 68: 1.029-1.031.

78. Essayan DM, Kagey-Sobotka A, Lichtenstein LM, et al. Paclitaxel hypersensitivity revisited. J Clin oncol $1996 ; 14: 1.042$.

79. Sekine 1, Nishiwaki Y, Watanabe K, Yoneda S, Saijo N. Phase 11 study of 3-hour infusion of paclitaxel in previously untreated non-small cell lung cancer. Clin Cancer Res 1996; 2: 941-945.

80. Bookman MA, Kloth DD, Kover PE, et al. Short-course intravenous prophylaxis for paclitexel-related hypersensitivity reactions. Ann Oncol 1997; 8: 611-614.

81. Sarosy G, Reed E. Taxol dose intensification and its clinical implications. J Natl Med Assoc 1993; 85: 427-431.

82. Rowinsky EK, Donehower RC. Paclitaxel (taxol). N Engl J Med 1995; 332: 1.004-1.014.

83. Stemmer SM, Cagnoni PJ, Shpall EJ, et al. High-dose paclitaxel, cyclophosphamide, and cisplatin with autologous hematopoietic progenitor-cell support: a phase I trial. J Clin Oncol 1996; 14: 1.463-1.472.

84. Goldberg HL, Vannice SB. Pneumonitis related to treatment with paclitaxel. J Clin Oncol 1995; 13: 534535 .

85. Ramanathan RK, Belani CP. Transient pulmonary infiltrates: a hypersensitivity reaction to paclitaxel. Ann Intern Med 1996; 124: 278.

86. Ramanthan RK, Reddy VV, Holbert JM, Belani CP. Pulmonary infiltrates following administration of paclitaxel. Chest 1996; 110: 289-292.

87. Reckzeh B, Merte $\mathrm{H}$, Pfluger $\mathrm{KH}$, Pfab R, Wolf M, Havemann $\mathrm{K}$. Severe lymphocytopenia and interstitial pneumonia in patients treated with paclitaxel and simultaneous radiotherapy for non-small cell lung cancer. J Clin Oncol 1996; 14: 1.071-1.076.

88. Lebeau B, Urban T, Brechot JM, et al. A randomized clinical trial comparing concurrent and alternating thoracic irradiation for patients with limited small cell lung carcinoma. «Petites cellules» Group. Cancer 1999 ; 86: 1.480-1.487.

89. Oral EN, Bavbek S, Kizir A, et al. Preliminary analysis of a phase II study of paclitaxel and CHART in locally advanced non-small cell lung cancer. Lung Cancer 1999; 25: 191-198.

90. Robert F, Childss HA, Spencer SA, Redden DT, Hawkins MM. Phase I/II study of concurrent paclitaxel and cisplatin with radiation therapy in locally advanced non-small cell lung cancer: analysis of early and late pulmonary morbidity. Semin Radiat Oncol 1999; 9 (Supl 1) : 136-147.

91. Langer $G J$, Movsas $B$, Hudes $R$, et al. Induction paclitaxel and carboplatin followed by concurrent chemoradiotherapy in patients with unresectable, locally advanced non-small cell lung carcinoma: report of Fox Chase Cancer Center study 94-001. Semin Oncol 1997; 24 (Supl 12) : 89-95.

92. Antonia SJ, Wagner H, Williams C, et al. Concurrent paclitaxel/cisplatin with thoracic radiation in patients with stage IIIA/B non-small cell carcinoma of the lung. Semin Oncol 1995; 22: 34-37.

93. Robert F, Childs HA, Spencer SA, Redden DT, Hawkins MM. Phase 1/IIa study of concurrent paclitaxel and cisplatin with radiation therapy in locally advanced non-small cell lung cancer: analysis of early and late pulmonary morbidity. Semin Radiat Oncol 1999; 9 (Supl 1): 136147.

94. Bonomi P, Faberr LP, Warren W, et al. Postoperative 
cidad pulmonar inducida por la quimioterapia.

Palabras clave: cáncer de pulmón, quimioterapia, toxicidad pulmonar. 
bronchopulmonary complications in stage 111 lung cancer patients treated with preoperative paclitaxelcontaining chemotherapy and concurrent radiation. Semin Oncol 1997; 24: 123-129.

95. Etienne B, Perol M, Nesme P, Vuillermoz S, Robinet G, Guerin JC. Acute diffuse interstitial pneumopathy following docetaxel (Taxotere). A propos of 2 cases. Rev Mal Respir 1998; 15: 199-203.

96. Maksymiuk AW, Marschke RJ, Tazelaar HD, et al. Phase 11 trial of topotecan for the treatment of mesothelioma. Am J Clin Oncol 1998; 21: 610-613.

97. Rothenberg ML, Kuhn JG, Burris HA 1ll, et al. Phase I and pharmacokinetic trial of weekly CPT-11. J Clin oncol 1993; 11: 2.194-2.204.

98. Masuda N, Fukuoka M, Kusunoki YJ, et al. CPT a new derivate of camptothecin for the treatment of refractory or relapsed small-cell lung cancer. J Clin OnCol 1992; 10: 1.225-1.229.

99. Fukuoka M, Niitani H, Susuki A, et al. A phase 11 study of CPT-11, a new derivate of camptotheicin, for previously untreated non-small-cell lung cancer. J Clin Oncol 1992; 10: 16-20.

100. Masuda N, Fukuoka M, Kusunoki Y, et al. CPT-11: a new derivative of camptothecin for the treatment of refractory or relapsed small-cell lung cancer. J Clin Oncol 1992; 10: 1.225-1.229.

101. Takeda K, Negoro S, Kudoh S, et al. Phase 1/11 study of weekly irinotecan and concurrent radiation therapy for locally advanced non-small cell lung. $\mathrm{Br} \mathrm{J}$ Cancer 1999; 79: 1.462-1.467.

102. Gurjal A, An T, Valdivieso M, Kalemkerian GP. Etoposide-induced pulmonary toxicity. Lung Cancer 1999; 26: 109-112.

103. Dajczman E, Srolovitz H, Kreisman H, Frank H. Fatal pulmonary toxicity following oral etoposide therapy. Lung Cancer 1995; 12: 81-86.

104. O'Dwyer P, Weiss RB. Hypersensitivity reactions induced by etoposide. Cancer Treat Rep 1984; 68: 959-961.

105. Sleijfer S, Van der Mark TW, Schraffordt Koops H, et al. Decrease in pulmonary function during bleomycincontaining combination chemotherapy for testicular cancer: not only a bleomycin effect. Br J Cancer 1995; 71: 120-123.

106. Kasturi VK, Dearing MP, Piscitelli SC, et al. Phase I study of a five-day dose schedule of 4-ipomeanol in patients with non-small cell lung cancer. Clin Cancer Res 1998; 4: 2.095-2.102. 